\title{
German minister backs national academy
}

Munich. Jürgen Rüttgers, Germany's new minister of education, science, research and technology, promised in his inaugural speech to the Bundestag, the federal parliament, last week that the government would increase its funding of research and technology.

In a speech that won the backing of the main opposition party, the Social Democrats (SPD), he also promised to promote the government's efforts to create a national academy of sciences, to reduce the burden of regulation on the country's scientists and to reduce the amount of time spent by German students at university before entering employment.

But achieving such goals may be easier said than done - existing regional bodies will oppose the new academy and shortly after Rüttgers' speech, the federal finance minister indicated that there would be no extra money for science in 1995.

Rüttgers was speaking the day after the German chancellor, Helmut Kohl, had outlined the government's plan for the next four years. Kohl said that one of its chief goals was to make the country "fit for the twenty-first century", and added that it needed "an alliance for the future" - - seen by some as an allusion to the informal name of Rüttger's new department as the 'ministry for the future'. Rüttgers said that while maintaining Germany's generous funding of basic science, he planned to spend more on the development of key technologies. Another top priority, he said, was to tackle overcrowding in universities.

\section{Patents stalemate on biotechnology}

Paris. Attempts to reach agreement on a $\mathrm{Eu}-$ rope-wide directive aimed at harmonizing legislation on biotechnology patents among the 12 member states of the European Union reached an official stalemate on Monday, when representatives from the Council of Ministers and the European Parliament failed to agree to a single text.

Agreement through such a 'conciliation committee' is required under the new procedures of the Maastricht treaty. But the Council of Ministers, which represents the governments of the EU states, refused to accept an amendment from the parliament that would have forbidden patents on isolated parts of the human body - including genes and cell lines. The parliament refused to budge either, reflecting its deeply held views on this issue (see Nature 372, 310; 1994).

If a compromise is to be reached, it will have to be found quickly. Procedures provide only weeks in which to hold another 'conciliation' meeting. If this committee eventually rejects the parliament's amendment, its decision could still be overturned by an absolute majority vote in the parliament, but many may not wish the issue to be taken to a vote. Declan Butler

Referring to Germany's notoriously over-bureaucratized regulatory laws on issues such as the use of chemicals and research on animals, Rüttgers said that science "should be given the breathing space it needs", promising to reduce barriers to creativity and competitiveness.

He also acknowledged that there were limits that scientific progress should respect - particularly those relating to the dignity of the individual.

Rüttgers has long been a proponent of plans to establish a national academy of science, modelled on that of the United States and intended to provide a both a national focus for the scientific community, and a point of contact with similar organizations in other countries. He was also largely responsible for setting up the

\section{Protests greet Italian budget cuts}

Rome. A cross-party initiative in the Italian parliament is expected to block an attempt by the research minister, Stefano Podestá, to impose stringent cuts on the budget of the National Agency for New Technology, Energy and the Environment (ENEA).

The proposed cuts are the only seriously contentious issue in proposals put forward by Podestá last month for a nogrowth budget for research in Italy for 1995 . The budgets of the National Research Council (CNR) and the Italian Space Agency (ASI) are likely to be held at the same

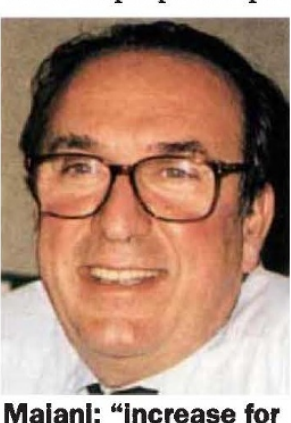
Maiani: "increase for physics is Illusory." level as this year, namely L1,040 billion (US\$655 million) and L850 billion respectively.

Only the National Institute for Nuclear Physics (INFN) is earmarked for a rise, from L400 billion to L470 billion. But Luciano Maiani, head of the institute, says this is primarily intended to compensate for a 10 per cent cut this year.

Furthermore, the INFN will have to divert five per cent of its 1995 budget to a fund administered by the research ministry to support research in small and medium-sized enterprises for work related to physics.

But ENEA, which Podestá considers inefficient and lacking in focus, was singled out for a cut of 21 per cent, from L508 billion to L400 billion. Initially established to develop nuclear energy,
Bundestag's office of technology assessment (see Nature 372, 311; 1994).

In his speech to parliament, Rüttgers said he would like the proposed academy, which would represent both natural and social sciences, to serve as a forum for discussing scientific problems at a national and international level. But learned societies in many of Germany's Länder have given this idea a cool reception, fearing that a national academy would detract from their own prestige and challenge their independence.

The SPD's support for Rüttgers' initiatives is likely to be particularly important in the case of university reforms, which reflect a long-standing goal of Chancellor Kohl. Universities are the responsibility of the Länder, and the majority of Länder prime ministers are social democrats.

the agency was forced to change direction when Italy voted in a referendum 10 years ago to abandon further development of nuclear power.

Nicola Cabbibo, ENEA's president, acknowledges that the change in research direction was not easy for the large agency, which has in the past employed up to 5,000 staff. He also says that although ENEA has been left with a broad portfolio of activities, this does not mean that it has no focus.

Since his appointment last July, Cabbibo has been working to improve efficiency and reduce staff numbers, and he says that he is upset by Podestá's efforts to try to force his hand by simply cutting off support.

Cabbibo claims that his views have substantial support in parliament and is optimistic that his agency will be given a reprieve.

In parallel to the budget proposal, Podestá has also put forward a bill to create an interministerial committee to restructure Italian research. No details about how this committee might work have been published. But the bill could give the government stronger powers to create or close institutes without consulting the research organizations themselves.

It would also probably force external evaluations on all research institutes that are not subject to such independent scrutiny at present, a plan introduced by Podestá's predecessor, Umberto Colombo, earlier this year.

Cabbibo would welcome the idea of external evaluations of ENEA institutes if members of evaluation committees were from abroad. He fears that because the move is tightly linked to budget discussions, the motivation for the evaluations is to make further cuts. But he is reserving final judgement until more details are known.

Alison Abbott 